\title{
Mentoring For Professional Development In Universities In Rivers State, Nigeria
}

\author{
Kenneth K. Obasi, Ph. D \\ Department Of Educational Management \\ University Of Port Harcourt \\ Port Harcourt, Nigeria \\ Adanma N. Ohia, Ph. D \\ Department Of Educational Management \\ University Of Port Harcourt \\ Port Harcourt, Nigeria
}

\begin{abstract}
The study investigated the level of mentoring for professional development in the universities in Rivers State. The study adopted the descriptive survey design. Four research questions guided the study. The population of the study comprised all the three universities in Rivers State. All the lecturers in the three universities constituted the population of the respondents. The sample size of the respondents was 120 lecturers (30 HODs and 90 other lecturers). The instruments for the study were questionnaire and structured interview. The questionnaire was validated and tested for reliability with Crombach Alpha with reliability indices of $0.86,0.84,0.88$ and 0.89 respectively. Mean and Standard Deviation were used to answer the research questions. The study revealed that the only official policy on mentoring was the directive of the National Universities Commission on the use of the recommended staff - mix - ratio for mentoring. In the three universities, there is no formalized platform or framework for mentoring for staff development, except in some cases where research assistants are assigned to professors to guide them and supervise their thesis. There is little or no institutional provision for mentoring. It was therefore recommended that the NUC and the individual universities should come up with more realistic and effective polices on mentoring. Each department should have a mentoring committee or coordinator for effective packaging and implementation of mentoring.
\end{abstract}

\section{INTRODUCTION}

University education is an arm of tertiary education which is saddled with some critical responsibilities in the drive for socio-economic development. It is strategic to national development. The goals of university education as enunciated by the Federal Republic of Nigeria (2004) in her National Policy on Education, inter alia, include contributing to national development through high level relevant manpower training, developing the intellectual capacity of individuals to understand and appreciate their local and external environments, the acquisition of both physical and intellectual skills which will enable individuals to be selfreliant and useful members of the society to promote and encourage scholarship and community service. These goals are therefore to be pursued through teaching, research and development, generation and dissemination of knowledge, virile staff development programmes, among others. University education therefore stands for the totality of general and specialized knowledge and skills that enable its beneficiaries to solve problems that they encounter in industry or in carrying out scientific research in a specialized area of knowledge. (The Free Dictionary, 2014) 
The tide of changes sweeping across the globe in the different spheres of life have continued to raise the bar of performance, compliance and relevance of university education in the 21st century. To that extent, UNESCO (1998) cautioned that in this age of technology, technology must be used in the service of teaching and research. Also, it should contribute to a more efficient management of higher education systems. Higher education is therefore expected to train citizens to think clearly, analyze problems, make choices, act ethically and assume their responsibilities. One important factor in this whole process of ensuring that the universities live up to these statutory responsibilities is the teacher. In this process, the university lecturer is basically involved in teaching, research and development, community service and also administration. These are the fundamental aspects of university education that can either make or mar the very essence of its establishment. Hence, the lecturers, just like other teachers at the different levels of education, are critical to the effectiveness of university education. The quality of university teaching manpower is therefore an administrative responsibility in this arduous task of human capacity building.

The increased competitiveness occasioned by technological advancements in the global market space has its corresponding demand on university education, precisely in its statutory responsibility of developing high level relevant human capital for the world of work. Ipso facto, the continued professional development of the teaching manpower is an imperative. Great teachers help to create great students. According to research an inspiring and informed teacher is the most important school - related factor that influence student achievement. Hence, it is critical to pay close attention to how we train and support both new and experienced teachers. It is critical for veterans and young teachers to have ongoing and regular opportunities to learn from each other. Ongoing professional development keeps teachers up-to-date on new research, emerging technology tools, new curriculum resources (Edutopia, 2008). Professional development entails many types of educational experiences related to an individual's work. Through it, they learn to apply new knowledge and skills that will improve their performance on the job. Hence, for teachers to be as effective as possible, they continually expand their knowledge and skills to implement the best educational practice (Mizell, 2010). One of the strategies for professional development is mentoring.

Mentoring is a process that involves two people, an experienced and less experienced person in which the more experienced person guides, supports, nurtures and encourages the less experienced to grow and develop in the area of life. It often takes place in organizations. It is relationship based, built and founded on trust and openness. Anderson, in The Alberta Teachers Association (2008) described mentoring as a nurturing process in which a skilled person serves as a role model, teaches, sponsors, encourages, counsels and befriends a less skilled or experienced person for the purpose of promoting the latter's professional development. It involves a caring relationship between the mentor and the protégé. Mentoring could be formal or informal. The Association provided two models for the two types. In the informal model, the mentor provides teaching materials, classroom teaching strategies for the benefit of the protégé. This could be refered to as the apprenticeship model in which the competence level of the mentor does not increase. Hence, neither reflective practice nor action research takes place and professional growth is restricted. Under formal mentoring, the mentor goes beyond sharing of materials and moves into the development of materials within a collaborative team. It entails reflective practice, collaborative planning and action research coupled with a joint action plan by the mentor and the mentee. Through this process, both the mentor and the mentee rise to new heights of professional growth and competence. 
Mentoring enhances professional competence and confidence. Career development mentoring provides the employees the platform for goal congruence and the ability to advance professionally. The collaboration gives the employee a feeling of engagement. Informal mentoring takes place where it is not formally organized, in which case, the organization only encourages the more experienced persons to accept mentoring requests from the less experienced members of the organization. However, in a formal setting, organized mentoring programmes are packaged, both the mentor and the mentee complete a mentoring profile. The mentoring profile are completed and documented. The protégés are matched with a mentor by a programme administrator or a mentoring committee (Daloz, 1990). The specific issues that the mentor should consider include the frequency of contact (face to face, phone calls, emails), the duration of the partnership, the review of the partnership, the skills, knowledge and experience to be offered to mentee and confidentiality of partnership information. In developing a mentoring partnership, it is important that boundaries are properly delineated on what the mentor can and cannot offer the mentee (Mind Tool, 2016).

The task of mentoring is relationship based and must be carried out within the limits of professional demand. The mentor is therefore expected to prepare and implement a joint mentorship growth plan with the protégé, maintain a relationship consistent with the Code of Professional Conduct, observe and provide feedback to the protégé, assist the mentee in identifying personal strengths and planning for further professional growth and development (The Alberta Teachers Association, 2008). The need for the organization of formal mentoring in schools has become imperative because new teachers juggle an overwhelming number of unfamiliar issues such as classroom management, instruction, curriculum, school culture and operations and administration. Left to themselves, they may develop counter productive behaviours. With extra support, the less experienced teachers will learn more effective practices to apply to daily challenges (Mizell, 2010).

\section{Statement of the problem}

University education is strategic to national development when analyzed from the point of view of its statutory responsibility of developing high level relevant manpower for the national economy. This critical role is carried out through teaching, research and development and community service. At the centre of this process is the teacher who is a significant factor in the process of human capacity building. The quality of the teacher significantly determines the quality of the products of the system. One critical factor in ensuring this quality is continuous teacher professional development of which mentoring is one of the strategies. Hence, a close study of some Nigerian universities reveal that there are issues and cases that are at variance with what they stand for and at the same time, a grave obstacle to the realization of the statutory goals and objectives of teaching - learning task, poor management of critical issues that concern both the staff and students, poor quality research, malpractices in research related issues, unethical practices and professional misconduct. The concern of this study is: could it be that mentoring is not utilized to support the less experienced teachers? Could it be that mentoring is not given adequate attention in the universities? Could it be that there are no administrative provisions for formal mentoring? Is it only carried out at the informal level?

\section{Aim and objectives of the study}

The aim of the study was to determine the level at which mentoring is carried out in the universities in Rivers State. Specifically, the objectives of the study were to determine the following:

- the level of institutional provision for mentoring in universities in Rivers State

- the level of mentoring activities that take place in universities in Rivers State

- the attitude of the lecturers of the universities in Rivers State towards mentoring 
- the challenges that impede mentoring in universities in Rivers State

\section{Research Questions}

The following research questions guided this study

- What is the level of institutional provision for mentoring in universities in Rivers State?

- What is the level of mentoring activities that take place in universities in Rivers State?

- What is the attitude of the lecturers of the universities in Rivers State towards mentoring?

- What are the challenges that impede mentoring in universities in Rivers State?

\section{METHODOLOGY}

The study adopted the descriptive survey design. The population of the study comprised all the three universities in Rivers State. The respondents were all the Heads of Departments and all the lecturers in the three universities. The sample size of the respondents was 120 (HODs = 30 , lecturers $=90$ ). Stratified random sampling technique was used and each university served as a stratum. The instruments used for data generation were questionnaire and structured interview. Mean and Standard Deviation were used to answer the research questions.

\section{RESULTS}

Research Question 1: What is the level of institutional provision for mentoring in universities in Rivers State?

Table 1: Mean and Standard Deviation of the opinions of the HOD's and other lecturers on the level of institutional provision for mentoring in universities

\begin{tabular}{|c|l|c|c|c|}
\hline S/N & \multicolumn{1}{|c|}{ Questionnaire items } & Mean & SD & Remarks \\
\hline 1 & $\begin{array}{l}\text { There is a university policy that makes mentoring } \\
\text { mandatory }\end{array}$ & 2.68 & 0.95 & Accepted \\
\hline 2 & $\begin{array}{l}\text { There is a functional mentoring committee in the } \\
\text { departments }\end{array}$ & 1.23 & 0.42 & Rejected \\
\hline 3 & $\begin{array}{l}\text { There is a functional mentoring coordinator in the } \\
\text { departments }\end{array}$ & 1.39 & 0.49 & Rejected \\
\hline 4 & $\begin{array}{l}\text { Workshops and seminars are regularly organized to } \\
\text { increase the awareness on the advantages of mentoring }\end{array}$ & 1.32 & 0.47 & Rejected \\
\hline 5 & $\begin{array}{l}\text { Workshops and seminars are regularly organized for } \\
\text { mentors }\end{array}$ & 1.15 & 0.36 & Rejected \\
\hline
\end{tabular}

Table 1 shows that out of the five items on the institutional provision for mentoring, only item 1 has mean value of 2.68 which is above the criterion mean of 2.50 . The other items were below the criterion mean. Hence, those provisions are not made.

Research Question 2: What is the level of mentoring activities that take place in universities in Rivers State? 
Table 2: Mean and Standard Deviation of the opinions of the HOD's and other lecturers on the level of mentoring activities that take place in universities

\begin{tabular}{|c|l|l|l|l|}
\hline S/N & \multicolumn{1}{|c|}{ Questionnaire items } & Mean & SD & Remarks \\
\hline 1 & $\begin{array}{l}\text { Mentoring is utilized as an induction strategy for new } \\
\text { lecturers }\end{array}$ & 1.44 & 0.49 & Rejected \\
\hline 2 & $\begin{array}{l}\text { All the less experienced lecturers are assigned to a } \\
\text { mentor }\end{array}$ & 1.15 & 0.36 & Rejected \\
\hline 3 & The department provide templates for mentoring & 1.16 & 0.37 & Rejected \\
\hline 4 & $\begin{array}{l}\text { Mentoring activities are regularly evaluated by the } \\
\text { departments }\end{array}$ & 1.15 & 0.36 & Rejected \\
\hline 5 & $\begin{array}{l}\text { The mentors and the mentees collaboratively work out } \\
\text { the modalities for mentoring }\end{array}$ & 1.14 & 0.35 & Rejected \\
\hline 6 & $\begin{array}{l}\text { The departments provided the guidelines/modalities } \\
\text { for mentoring }\end{array}$ & 1.18 & 0.38 & Rejected \\
\hline
\end{tabular}

Table 2 shows that all the mentoring activities are not carried out in the institutions because mean values of all the six items were below the criterion mean of 2.50

Research Question 3: What is the attitude of the lecturers of the universities in Rivers State towards mentoring?

Table 3: Mean and Standard Deviation of the opinions on the attitude of the lecturers towards mentoring

\begin{tabular}{|c|l|l|c|l|}
\hline S/N & \multicolumn{1}{|c|}{ Questionnaire items } & Mean & SD & Remarks \\
\hline 1 & $\begin{array}{l}\text { Junior lecturers do not show sufficient interest in being } \\
\text { mentored }\end{array}$ & 2.35 & 0.90 & Rejected \\
\hline 2 & $\begin{array}{l}\text { The more experienced lecturers do not show sufficient } \\
\text { in mentoring the less experienced ones }\end{array}$ & 2.96 & 0.82 & Accepted \\
\hline 3 & $\begin{array}{l}\text { The less experienced lecturers do not have much } \\
\text { confidence in the more experienced ones }\end{array}$ & 2.85 & 0.86 & Accepted \\
\hline 4 & $\begin{array}{l}\text { The less experienced lecturers are enthusiastic about } \\
\text { being mentored }\end{array}$ & 3.50 & 0.80 & Accepted \\
\hline
\end{tabular}

Table 3 reveals that out of the four items on the attitude of lecturers towards mentoring, only the first item had a mean below criterion mean (2.35).

Research Question 4: What are the challenges that impede mentoring in universities in Rivers State?

Table 4: Mean and Standard Deviation of the opinions on the challenges impeding mentoring

\begin{tabular}{|c|l|c|c|c|}
\hline S/N & \multicolumn{1}{|c|}{ Questionnaire items } & Mean & SD & Remarks \\
\hline 1 & $\begin{array}{l}\text { There is no formal provision by the institution for } \\
\text { mentoring }\end{array}$ & 2.87 & 0.89 & Accepted \\
\hline 2 & There is no formal guideline/format for mentoring & 3.40 & 0.85 & Accepted \\
\hline 3 & $\begin{array}{l}\text { The official schedules of the lecturers are too tight for } \\
\text { mentoring }\end{array}$ & 2.96 & 0.82 & Accepted \\
\hline 4 & $\begin{array}{l}\text { Poor awareness of mentoring as a professional } \\
\text { development strategy among the lecturers }\end{array}$ & 1.58 & 0.49 & Rejected \\
\hline 5 & Poor facilities provision & 2.61 & 0.89 & Accepted \\
\hline
\end{tabular}


On the challenges impeding mentoring in universities, Table 4 reveals that out of the five items identified as challenges, only item 4 had a mean value of 1.58 which is below the criterion mean of 2.50. The other items were above the criterion mean. Hence, they are identified as challenges.

\section{DISCUSSION OF FINDINGS}

On the issue of institutional provision for mentoring which the first research question sought to address, the study revealed that in principle, mentoring is institutionally provided as required by the National Universities Commission (NUC) by adhering to the $20-35-45$ staff mix ratio. By the policy of the NUC, the regulatory body for quality and standardization of the Nigerian universities, universities are required to use the staff - mix - ratio as a platform for mentoring. However, its implementation leaves much to be desired as shown by the other indicators that reveal that little or nothing is in place for formal mentoring. This position was corroborated by the findings of the second research question on the level of mentoring in the universities. The study revealed that nothing much is being done except for situations where graduate assistants are assigned to some professors for guidance and thesis supervision. The poor emphasis on mentoring was corroborated by Amiehenomo (2002) who observed that despite the importance of mentoring in professional development, it has not been given any serious attention in Nigerian educational policies. In the same vein, Dadey and Harber in Olaniyan (1998) remarked that few countries in Africa have comprehensive training prrogramme in educational administration and planning.

The third research question on the attitude of the lecturers towards mentoring revealed that, though the young lecturers are eager to be mentored, but the response from the more experienced colleagues is not inspiring. Though, there is some level of apathy among the younger lecturers, the senior colleagues do not show convincing commitment to assisting the younger ones through mentoring. The findings also show that a lot of challenges are impending effective mentoring. They include poor policy provision on mentoring, lack or inadequate formal guidelines and framework for mentoring. The crowded programmes of the lecturers is also a challenge.

\section{CONCLUSION}

Although, the National Universities Commission (NUC) recommended that approved staff mix ratio should be used as the platform for mentoring, its effective implementation remains a mirage. From the findings of the study therefore, it was concluded that policy provision for mentoring is grossly inadequate. Hence, mentoring, as a formal strategy for lecturers professional development is almost non-existent. It was also concluded that the different universities have not made provisions for mentoring and this has negatively impacted on the attitude of some lecturers towards mentoring. It was also concluded that the tight schedules of lecturers, poor facilities provision impede mentoring in the universities.

\section{RECOMMENDATIONS}

On the strength of the findings of the study, the following recommendations were made:

- Every institution should have a comprehensive and integrated plan for mentoring programmes which should be regularly evaluated.

- The National Universities Commission and the individual universities should come up with more realistic and effective policies on mentoring beyond the use of staff - mix ratio.

- Departments should have a mentoring committee or coordinator for effective packaging and implementation of mentoring in the universities. 
- The very experienced lecturers should take the lead and at the same time, encourage the young ones to embrace mentoring.

- The less experienced lecturers should also be proactive in this regard by taking the initiative of by at the feet of the more experienced colleagues especially where there are no adequate institutional provision for mentoring.

- More facilities should be provided for both the mentors and the mentee in order to create a conducive atmosphere for mentoring.

\section{References}

Amiebeomo, A. B. (2002). Effective administration in the secondary school system: Journal of ANCOPSS, 15 (2), 16

Daloz, L. A. (1990). Effective teaching and mentoring. San Francisco: Josey Bass

Edutopia (2008). Why is teacher development important?: because students deserve the best. Retrieved from http://www.edutopia.org/teacher-devlopment-introduction

Federal Republic of Nigeria (2004). National Policy on Education. Lagos: NERDC

Mind Tools (2016). Mentoring: an essential leadership skill. Retrieved from

http://www.Mindtools.com/pages/article/newCDV_70.htm

Mizell, H (2010). Why professional development matters. Retrieved from

http://www.Learningforward.org/docs/pdf/why_pd_matters_web-pdf

Olananiya, A. B. (1998). Principles: preparation, selection and leadership roles. In N. A. Nwagwu (Ed) Teacher and teacher in Nigeria issues, challenges and prospects. Benin: FESTA

Rebore, R. W. (2011). Human resources administration in education: a management approach (9th ed). New York: Pearson

The Free Encyclopedia (2014). University education. Retrieved from

http://encyclopedia2thefreedictionary.com/universityeducation

UNESCO (1998). World conference on Higher Education: Vision and Action. Retrieved from

http://www.unesco.org/education/educprog/wche/diaz- e.htm 